\title{
TREES OF Taxodiaceae FAMILY CULTIVATED ON DIFFERENT STANDS IN WROCŁAW
}

\section{DRZEWA Z RODZINY Taxodiaceae UPRAWIANE NA RÓŻNYCH STANOWISKACH WE WROCŁAWIU}

Department of Horticulture, Wrocław University of Environmental and Life Sciences, Poland

\begin{abstract}
Strzeszczenie. Drzewa należące do rodziny Taxodiaceae są rzadko uprawiane w polskich warunkach klimatycznych ze względu na ich pochodzenie z cieplejszych regionów świata. Celem niniejszej pracy było opracowanie stanu odżywienia drzew z rodziny Taxodiaceae rosnących zarówno na terenach Wrocławia, które zachowały cechy pierwotnych lasów łęgowych oraz grądowych, jak i rosnących na stanowiskach przekształconych antropogenicznie. W 2013 roku na terenie Wrocławia zlokalizowano 3 stanowiska szydlicy japońskiej, gdzie rosły 3 drzewa. Metasekwoja chińska rosła na 2 stanowiskach, gdzie łącznie było 9 drzew. Odnotowano sześć stanowisk cypryśnika błotnego, gdzie rosło 11 drzew. Pomimo różnic w zawartości chlorofilu i poziomu odżywiania żadne z drzew nie wykazywało widocznych niedoborów składników pokarmowych. Wyniki wskazują, że drzewa z rodziny Taxodiaceae mogą rosnąć na terenach zieleni miasta Wrocławia.
\end{abstract}

Key words: baldcypress, dawn redwood, Japanese cedar, Wroclaw green areas.

Słowa kluczowe: cypryśnik błotny, metasekwoja chińska, szydlica japońska, Wrocław, tereny zieleni.

\section{INTRODUCTION}

Wrocław is characterized by the typical features of temperate zone. The length of vegetation period is average 226 days (the longest in Poland) and means total days with the air temperature exceeding $5^{\circ} \mathrm{C}$ (Dubicka et al. 2002, 2003). Moreover, Wrocław is situated in the warmest region of Poland, with the average annual air temperature exceeding $8.7^{\circ} \mathrm{C}$ (Dubicka and Dubicki 2002). Important climatic issue of Wrocław city is increased temperature, so-called urban heat island (UHIs). It was proven, that in the summer the local temperatures in the city can reach $44-55^{\circ} \mathrm{C}$ (Dubicka and Chudzia 1998; Dubicka and Szymanowski 2000). The warmest month is July with the average temperature of $18.4^{\circ} \mathrm{C}$ and the coldest is January $-1.1^{\circ} \mathrm{C}$. The frost-free period lasts 270 days (Dubicka et al. 2002). The average annual precipitation is about $592 \mathrm{~mm}$. On the compact build-up areas rainfalls are higher, while in peripheral districts annual precipitations may be lower up to $11 \%$ (Dubicka 2000; Dubicka and Dubicki 2006).

Corresponding author - Adres do korespondencji: Magdalena Pancerz, Department of Horticulture, Wrocław University of Environmental and Life Sciences, Grunwaldzki Sq. 24a, 50-375 Wrocław, Poland, e-mail: magdalena.pancerz@up.wroc.pl 
Favorable climatic conditions of Wrocław city and specific microclimate are very suitable for growing many interested taxa of introduced trees that are planted in green areas of the city. This fact is related to the primary origin of these areas, previously covered by forests. Particularly noteworthy are Szczytnicki Park and Strachociński Park that have arisen as a result of the conversion of riparian and mixed broadleaved forests. Trees of Taxodiaceae family are seldom planted in urban areas because of their specific habitat requirements. To the Taxodiaceae family belongs 10 relict genus scattered across the globe. There are no representatives of this family in European flora. They come mostly from subtropical areas of the Far East and North America and only one genus exists on the Tasmania island.

Baldcypress Taxodium distichum (L.) Rich., dawn redwood Metasequoia glyptostroboides $\mathrm{Hu}$ et W.C. Cheng and Japanese cedar Cryptomeria japonica (L.f.) D. Don in the areas of their natural habitats are forest-forming, as well as usable species. The most popular are primarily forest plantation of dawn redwood and Japanese cedar. The above-described taxa have been successfully introduced in climatic conditions of Europe, including the western Poland. In Poland trees of Taxodiaceae family are present primarily in botanical gardens and arboreta: Cryptomeria japonica (L.f.) D. Don - Japanese cedar, Cunninghamia lanceolata (Lamb.) Hook. - China-fir, Metasequoia glyptostroboides Hu et W.C. Cheng - dawn redwood, Sciadopitys verticillata (Thunb.) Siebold and Zucc. - Japanese umbrella trees, Sequoiadendron giganteum (Lindl.) J. Buchholz - giant sequoia and Taxodium distichum (L.) Rich. - baldcypress. In conditions of large urban agglomeration, which Wrocław is, baldcypress, dawn redwood and Japanese cedar had gone through the whole acclimatization cycle and successfully grow in the city greeneries, including areas of the primeval riparian and broadleaved forests.

Trees of Taxodiaceae family are usually resistant to diseases and pests but most of them for growth require mild climate, corresponding to the western part of Poland. Sufficiently resistant for our climate turned out to be two species. The first is baldcypress, sensitive as a young plant but with age becoming completely resistant to frost (Szymanowski 1957). It is also worth to note that although this species naturally occurs in wetlands along streams, it has a high tolerance to drought and grows well on almost all soil types, including heavy, compacted and poorly drained. However, faster growth is observed on moist and well drained soils (Gilman and Watson 1994b) The second species is dawn redwood with a natural range of occurrence including western Hubei, northern Hunan and east Sichuan, which are provinces in central China (Chu and Cooper 1950; Bartholomew et al. 1983). Originally known as fossil (Miki 1941), it was rediscovered as a living tree in China and described as a species shortly before World War II (Hu and Cheng 1948). Even from an early age this tree is almost completely resistant to frost. Periodic testing of dawn redwood solitary conducted over 50 years shows, that this species is able to grow in a wide range of climatic conditions (Hendricks and Søndergaard 1998; Kuser 1999). It is characterized by much faster growth than baldcypress. Very rare is cultivation of Japanese cedar, single trees in Lower Silesia region can be found e.g. in the manor park in Sulistrowice (HrynkiewiczSudnik 1977) and in Lądek Zdrój arboretum (Bąbelewski 2006). This species has very high demands for water (Nagakura et al. 2004) but tolerates compacted soil and irrigated during drought also withstands tough urban conditions (Gilman and Watson 1993). 
The aim of this study was to evaluate the conditions of growth and development, as well as nutritional status of trees belonging to Taxodiaceae family in urban areas of Wrockaw, primeval riparian and broadleaved forests.

\section{MATERIAL AND METHODS}

The study conducted in 2013 consisted of making an inventory of all stands of baldcypress, dawn redwood and Japanese cedar within the administrative boundaries of Wrocław city. As a stand was treated the area clearly separated with the exact location and its own name, e.g. an address. On each stand was specified the number of trees and measured the trunk circumference at height of $1.3 \mathrm{~m}$ above the soil surface and height of each of them with laser altimeter. In order to know on which soils grow trees from Taxodiaceae family the chemical analyzes of soil were performed. Soil samples were collected 2-3 August 2013. At each stand soil was taken from two layers of the soil profile: topsoil at a depth of $0-20 \mathrm{~cm}$ and subsoil at a depth of $20.1-40 \mathrm{~cm}$. To perform the chemical composition of soil from each level were taken 5 samples from different location within the stand, which, due to no statistical differences between them, were treated as repetitions and presented in tables as an averages. In the soil samples were determined $\mathrm{pH}$, EC and content of selected macronutrients. In order to measure chlorophyll content and selected macronutrients content in the needles from each tree with alpinistic methods were collected 20-25 short shoots samples from the whole volume of the crown to prepare 5 repetitions. Samples were collected 2-3.08.2013.

Measurements of EC were made with conductivity Meter and $\mathrm{pH}\left(\mathrm{H}_{2} \mathrm{O}\right)$ of the soil with a $\mathrm{pH}$ Meter. Magnesium and phosphorus content was determined using a spectrophotometric method described by Nowosielski (1974). Ca and K was determined by flame photometry method described by Faithfull (2002) and nitrates content with flow colorimetry described by Nowosielski (1974). Chlorophyll content was determined in $80 \%$ acetone by a spectrophotometric method. Leaf nitrogen was determined by Kjedahl method (Sreenivasan and Sadivasan 1939).

Data of trunk circumference and height of trees was compared numerously, while results of chemical analysis were subjected to the single-factor analysis of variance (ANOVA) and compared within the species using least significant difference followed by Tuckey's range test at the 0.05 significance level. No significant differences were noted among soil samples from one stand, thus the authors decided to place in the tables the averages for each stand.

\section{RESULTS}

In Wrocław were located three stands of Japanese cedar: the first was in the Japanese Garden and others on private estates on Radarowa Street and on Snopkowa Street. The largest trunk circumference had a tree growing on Radarowa Street, the other two had smaller trunk circumference. All trees of Japanese cedar were similar height (Table 1). 
Table 1. Trunk circumference and height of trees of family Taxodiaceae growing in the Wrocław area Tabela 1. Obwód pnia i wysokość drzew z rodziny Taxodiaceae rosnących na terenie Wrocławia

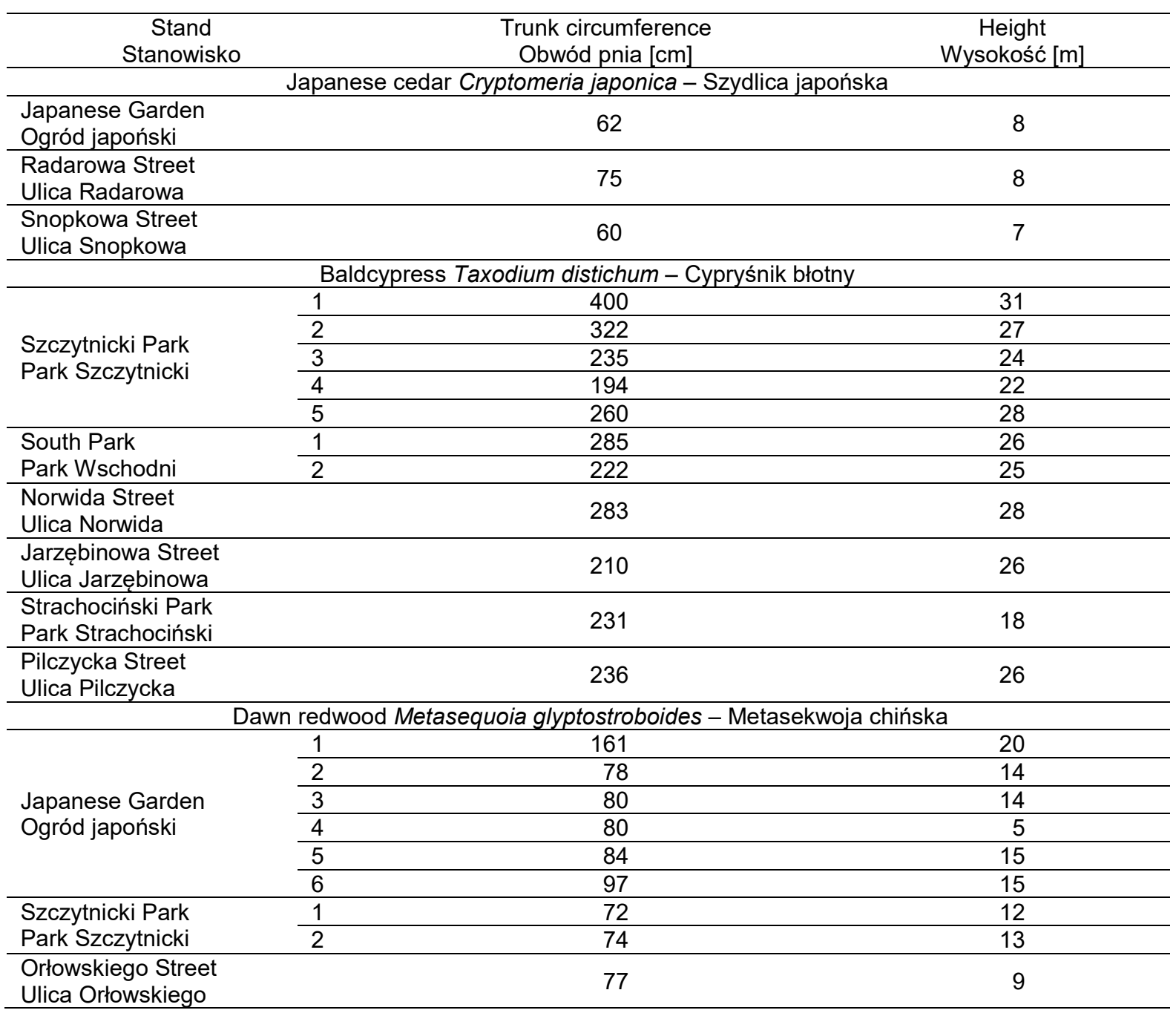

Richness of soil from stands of Japanese cedar in Wrocław differed within stands and tested macronutrients (Table 2). Despite the statistically insignificant differences there were observed fluctuations in the $\mathrm{pH}$ between the stands where the trees were grown. In the topsoil $0-20 \mathrm{~cm}$ the $\mathrm{pH}$ was higher and in the subsoil $20.1-40 \mathrm{~cm} \mathrm{pH}$ was lower. The differences in the topsoil EC were insignificant, while in the subsoil the highest EC was recorded on Radarowa Street and the lowest in the soil of the Japanese Garden. According to limit values of macronutrients in mineral soils, the analysis of soil from stands of Japanese cedar showed differences in richness of tested nutrients. Soil richness in magnesium on al stands of Japanese cedar was medium in both soil layers. However, in the topsoil differences were statistically not significant, while the richest was subsoil from Japanese Garden, where the content of this nutrient was close to high. The highest content of calcium was noted in both soil layers in Japanese Garden and in topsoil from Radarowa Street and Snopkowa Street, while was lowest in subsoil from both streets stands. The topsoil was characterized by very low content of phosphorus, while the subsoil samples from Radarowa Street and Snopkowa Street showed low content, what means that subsoil had higher phosphorus contents in compare to the topsoil. 
Table 2. Chemical properties of the soils from sites of trees of family Taxodiaceae growing in the Wrocław area

Tabela 2. Właściwości chemiczne gleby ze stanowisk drzew z rodziny Taxodiaceae, rosnących na terenie Wrocławia

\begin{tabular}{|c|c|c|c|c|c|c|c|c|c|c|c|c|c|c|}
\hline \multirow{3}{*}{$\begin{array}{c}\text { Stand } \\
\text { Stanowisko }\end{array}$} & \multicolumn{2}{|c|}{$\mathrm{pH}$} & \multicolumn{2}{|c|}{$\mathrm{EC}\left[\mu \mathrm{S} \cdot \mathrm{cm}^{-1}\right]$} & \multicolumn{2}{|c|}{$\mathrm{Mg}\left[\mathrm{mg} \cdot \mathrm{dm}^{-3}\right]$} & \multicolumn{2}{|c|}{$\mathrm{Ca}\left[\mathrm{mg} \cdot \mathrm{dm}^{-3}\right]$} & \multicolumn{2}{|c|}{$P\left[\mathrm{mg} \cdot \mathrm{dm}^{-3}\right]$} & \multicolumn{2}{|c|}{$\mathrm{K}\left[\mathrm{mg} \cdot \mathrm{dm}^{-3}\right]$} & \multicolumn{2}{|c|}{$\mathrm{N}-\mathrm{NO}_{3}\left[\mathrm{mg} \cdot \mathrm{dm}^{-3}\right]$} \\
\hline & \multicolumn{14}{|c|}{ Soil layers - Warstwy gleby } \\
\hline & $0-20$ & $20.1-40$ & $0-20$ & $20.1-40$ & $0-20$ & $20.1-40$ & $0-20$ & $20.1-40$ & $0-20$ & $20.1-40$ & $0-20$ & $20.1-40$ & $0-20$ & $20.1-40$ \\
\hline & \multicolumn{14}{|c|}{ Japanese cedar Cryptomeria japonica - Szydlica japońska } \\
\hline $\begin{array}{l}\text { Japanese Garden } \\
\text { Ogród japoński }\end{array}$ & $7.6 \mathrm{a}$ & $6.9 \mathrm{a}$ & $960 \mathrm{a}$ & $125 \mathrm{c}$ & $92 \mathrm{a}$ & $104 \mathrm{a}$ & $1180 a$ & $1290 a$ & 51 a & $63 \mathrm{~b}$ & $70 \mathrm{a}$ & 89 a & $23 \mathrm{a}$ & $43 a$ \\
\hline $\begin{array}{l}\text { Radarowa Street } \\
\text { Ulica Radarowa }\end{array}$ & $8.0 \mathrm{a}$ & $7.8 \mathrm{a}$ & $1004 a$ & $1080 a$ & $82 \mathrm{a}$ & $87 \mathrm{~b}$ & $1190 a$ & 1010b & 57 a & 87 a & $45 \mathrm{~b}$ & $67 \mathrm{~b}$ & $12 \mathrm{~b}$ & $32 \mathrm{~b}$ \\
\hline $\begin{array}{l}\text { Snopkowa Street } \\
\text { Ulica Snopkowa }\end{array}$ & $7.8 \mathrm{a}$ & $7.0 \mathrm{a}$ & $1000 a$ & $1070 b$ & $85 a$ & $90 \mathrm{~b}$ & $1100 a$ & 1000b & 53 a & $76 a b$ & 63 a & $71 \mathrm{~b}$ & $20 \mathrm{a}$ & $40 \mathrm{a}$ \\
\hline & \multicolumn{14}{|c|}{ Baldcypress Taxodium distichum - Cypryśnik błotny } \\
\hline $\begin{array}{l}\text { Szczytnicki Park } \\
\text { Park Szczytnicki }\end{array}$ & $6.3 \mathrm{~b}$ & $7.6 \mathrm{ab}$ & $218 \mathrm{c}$ & $227 \mathrm{~d}$ & $76 \mathrm{c}$ & $74 \mathrm{e}$ & $740 \mathrm{f}$ & $1820 d$ & $21 \mathrm{e}$ & $34 \mathrm{de}$ & $65 c$ & $40 \mathrm{e}$ & $107 \mathrm{~b}$ & $60 \mathrm{~b}$ \\
\hline $\begin{array}{l}\text { South Park } \\
\text { Park Wschodni }\end{array}$ & $6.8 \mathrm{ab}$ & $7.5 a b$ & $225 \mathrm{c}$ & $504 a$ & $92 \mathrm{~b}$ & $122 \mathrm{c}$ & $1000 \mathrm{e}$ & $2880 a$ & $55 \mathrm{c}$ & $31 \mathrm{e}$ & $60 \mathrm{c}$ & $25 \mathrm{f}$ & $15 \mathrm{e}$ & $15 \mathrm{e}$ \\
\hline $\begin{array}{l}\text { Norwida Street } \\
\text { Ulica Norwida }\end{array}$ & $7.0 \mathrm{ab}$ & $6.6 \mathrm{~b}$ & $153 d$ & $311 \mathrm{c}$ & $60 d$ & $46 \mathrm{f}$ & $2020 b$ & $700 \mathrm{f}$ & $76 \mathrm{~b}$ & $76 \mathrm{~b}$ & $110 \mathrm{~b}$ & $295 \mathrm{~b}$ & $56 \mathrm{~d}$ & $35 d$ \\
\hline $\begin{array}{l}\text { Jarzębinowa Street } \\
\text { Ulica Jarzębinowa }\end{array}$ & $6.2 \mathrm{~b}$ & $7.3 \mathrm{ab}$ & $218 c$ & $176 \mathrm{f}$ & $80 \mathrm{bc}$ & $92 \mathrm{~d}$ & $1520 d$ & $2720 b$ & 95 a & $91 \mathrm{a}$ & $70 \mathrm{c}$ & $65 d$ & $80 c$ & $48 \mathrm{c}$ \\
\hline $\begin{array}{l}\text { Strachociński Park } \\
\text { Park Strachociński }\end{array}$ & $7.0 \mathrm{ab}$ & $8.0 \mathrm{a}$ & $407 \mathrm{~b}$ & $349 b$ & $240 a$ & $234 b$ & $2200 a$ & $2360 c$ & $40 d$ & $41 d$ & $370 \mathrm{a}$ & $335 a$ & $54 \mathrm{~d}$ & $37 d$ \\
\hline $\begin{array}{l}\text { Pilczycka Street } \\
\text { Ulica Pilczycka }\end{array}$ & $7.4 \mathrm{a}$ & $7.6 a b$ & $777 \mathrm{a}$ & $216 \mathrm{e}$ & $38 \mathrm{e}$ & $246 a$ & $1960 c$ & $1220 \mathrm{e}$ & $69 \mathrm{~b}$ & $64 \mathrm{c}$ & $110 \mathrm{~b}$ & $80 c$ & $153 a$ & $72 a$ \\
\hline & \multicolumn{14}{|c|}{ Dawn redwood Metasequoia glyptostroboides - Metasekwoja chińska } \\
\hline $\begin{array}{l}\text { Japanese Garden } \\
\text { Ogród japoński }\end{array}$ & $7.6 \mathrm{a}$ & $6.9 \mathrm{a}$ & $96 \mathrm{c}$ & $125 \mathrm{~b}$ & $92 \mathrm{a}$ & $104 \mathrm{a}$ & $1180 a$ & $1290 b$ & $51 \mathrm{a}$ & $63 a$ & $70 \mathrm{a}$ & 89 a & $23 c$ & $43 \mathrm{c}$ \\
\hline $\begin{array}{l}\text { Szczytnicki Park } \\
\text { Park Szczytnicki }\end{array}$ & $6.4 \mathrm{~b}$ & $7.2 \mathrm{a}$ & $230 \mathrm{a}$ & $215 a$ & $78 \mathrm{~b}$ & $67 c$ & $680 \mathrm{~b}$ & $1490 a$ & $23 \mathrm{~b}$ & $34 \mathrm{c}$ & $60 \mathrm{~b}$ & $72 \mathrm{c}$ & $100 \mathrm{a}$ & 68 a \\
\hline $\begin{array}{l}\text { Orłowskiego Street } \\
\text { Ulica Orłowskiego }\end{array}$ & $6.6 \mathrm{~b}$ & $7.0 \mathrm{a}$ & $210 \mathrm{~b}$ & $130 \mathrm{~b}$ & $80 \mathrm{~b}$ & $75 \mathrm{~b}$ & $690 \mathrm{~b}$ & $1500 a$ & $41 a$ & $48 \mathrm{~b}$ & $67 \mathrm{ab}$ & $78 \mathrm{~b}$ & $67 \mathrm{~b}$ & $53 \mathrm{~b}$ \\
\hline
\end{tabular}

Values followed by the same letters in column within a species are not significantly different at the 0.05 level probability according to the Tukey's test - Wartości oznaczone tą samą literą w kolumnie w obrębie gatunku nie różnią się statystycznie na poziomie istotności 0,05, według testu Tukeya. 
According to potassium content, both soil layers richness was classified as very low. However, there was observed that in subsoil the content of this nutrient was higher in compare to the topsoil. In the case of nitrate nitrogen, in both layers of the soil profile, the highest content was found in soil derived from the Japanese Garden and Snopkowa Street, while the lowest in the soil from Radarowa Street.

Chlorophyll content in Japanese cedar needles depended on the stand. The highest chlorophyll a and total chlorophyll content was noted in tree growing on Snopkowa Street and the lowest was found in tree from the Japanese Garden. The highest chlorophyll b content had tree from the Japanese Garden, while the lowest the tree from Snopkowa Street (Table 3).

Table 3. Chlorophyll a, b and total chlorophyll content in needles of trees of family Taxodiaceae growing in the Wrocław area

Tabela 3. Zawartość chlorofilu a, b oraz całkowitego w igłach drzew z rodziny Taxodiace rosnących na terenie Wrocławia

\begin{tabular}{|c|c|c|c|c|}
\hline $\begin{array}{c}\text { Stand } \\
\text { Stanowisko }\end{array}$ & & $\begin{array}{c}\text { Chlorophyll a } \\
\text { Chlorofil a }\end{array}$ & $\begin{array}{c}\text { Chlorophyll b } \\
\text { Chlorofil b }\end{array}$ & $\begin{array}{c}\text { Total chlorophyll } \\
\text { Chlorofil całkowity }\end{array}$ \\
\hline \multicolumn{5}{|c|}{$\mathrm{mg} \cdot \mathrm{g}^{-1}$} \\
\hline \multicolumn{5}{|c|}{ Japanese cedar Cryptomeria japonica - Szydlica japońska } \\
\hline $\begin{array}{l}\text { Japanese Garden } \\
\text { Ogród japoński }\end{array}$ & & $0.432 \mathrm{c}$ & $0.290 \mathrm{a}$ & $0.611 \mathrm{c}$ \\
\hline $\begin{array}{l}\text { Radarowa Street } \\
\text { Ulica Radarowa }\end{array}$ & & $0.475 \mathrm{~b}$ & $0.263 \mathrm{ab}$ & $0.680 \mathrm{~b}$ \\
\hline $\begin{array}{l}\text { Snopkowa Street } \\
\text { Ulica Snopkowa }\end{array}$ & & $0.506 \mathrm{a}$ & $0.246 \mathrm{~b}$ & $0.730 \mathrm{a}$ \\
\hline \multicolumn{5}{|c|}{ Baldcypress Taxodium distichum - Cypryśnik błotny } \\
\hline \multirow{5}{*}{$\begin{array}{l}\text { Szczytnicki Park } \\
\text { Park Szczytnicki }\end{array}$} & 1 & $0.942 \mathrm{c}$ & 0.513 e & $1.352 \mathrm{e}$ \\
\hline & 2 & $0.982 \mathrm{~b}$ & $0.602 \mathrm{~b}$ & $1.397 \mathrm{~d}$ \\
\hline & 3 & $1.069 \mathrm{a}$ & $0.636 \mathrm{a}$ & $1.524 \mathrm{~b}$ \\
\hline & 4 & $0.996 \mathrm{~b}$ & $0.548 d$ & $1.393 d$ \\
\hline & 5 & $0.973 \mathrm{~b}$ & $0.597 \mathrm{~b}$ & $1.420 \mathrm{c}$ \\
\hline \multirow{2}{*}{$\begin{array}{l}\text { South Park } \\
\text { Park Wschodni }\end{array}$} & 1 & $0.822 \mathrm{e}$ & $0.505 \mathrm{e}$ & $1.169 \mathrm{~h}$ \\
\hline & 2 & $0.972 \mathrm{bc}$ & $0.559 \mathrm{~d}$ & $1.389 \mathrm{~d}$ \\
\hline $\begin{array}{l}\text { Norwida Street } \\
\text { Ulica Norwida }\end{array}$ & & $1.136 \mathrm{a}$ & $0.573 \mathrm{c}$ & $1.637 \mathrm{a}$ \\
\hline $\begin{array}{l}\text { Jarzębinowa Street } \\
\text { Ulica Jarzębinowa }\end{array}$ & & $0.663 \mathrm{~g}$ & $0.353 \mathrm{~h}$ & $1.307 \mathrm{f}$ \\
\hline $\begin{array}{l}\text { Strachociński Park } \\
\text { Park Strachociński }\end{array}$ & & $0.741 \mathrm{f}$ & $0.362 \mathrm{~g}$ & $1.070 \mathrm{i}$ \\
\hline $\begin{array}{l}\text { Pilczycka Street } \\
\text { Ulica Pilczycka }\end{array}$ & & $0.875 d$ & $0.442 \mathrm{f}$ & $1.261 \mathrm{~g}$ \\
\hline \multicolumn{5}{|c|}{ Dawn redwood Metasequoia glyptostroboides - Metasekwoja chińska } \\
\hline \multirow{6}{*}{$\begin{array}{l}\text { Japanese Garden } \\
\text { Ogród japoński }\end{array}$} & 1 & $1.260 \mathrm{~d}$ & $0.598 \mathrm{de}$ & $1.823 \mathrm{~d}$ \\
\hline & 2 & $0.776 \mathrm{~h}$ & $0.380 \mathrm{~g}$ & $1.120 \mathrm{~h}$ \\
\hline & 3 & $1.139 \mathrm{e}$ & $0.610 \mathrm{~d}$ & $1.635 \mathrm{e}$ \\
\hline & 4 & $1.296 \mathrm{c}$ & $0.670 \mathrm{~b}$ & $1.865 \mathrm{c}$ \\
\hline & 5 & $1.338 b$ & $0.643 \mathrm{c}$ & $1.935 \mathrm{~b}$ \\
\hline & 6 & $1.516 \mathrm{a}$ & $0.865 a$ & $2.168 \mathrm{a}$ \\
\hline \multirow{2}{*}{$\begin{array}{l}\text { Szczytnicki Park } \\
\text { Park Szczytnicki }\end{array}$} & 1 & $1.112 \mathrm{f}$ & $0.582 \mathrm{e}$ & $1.599 \mathrm{f}$ \\
\hline & 2 & $1.070 \mathrm{~g}$ & $0.564 \mathrm{f}$ & $1.538 \mathrm{~g}$ \\
\hline $\begin{array}{l}\text { Orłowskiego Street } \\
\text { Ulica Orłowskiego }\end{array}$ & & $1.292 \mathrm{c}$ & $0.639 \mathrm{c}$ & $1.864 \mathrm{c}$ \\
\hline
\end{tabular}

Explanations see Table 1 - Objaśnienia zob. tab. 1. 
Nutrition level of Japanese cedar needles depended on the stand only in the case of calcium and potassium. The highest content of calcium was found in needles of the tree growing on Snopkowa Street, while the lowest in needles from tree growing in the Japanese Garden. The highest content of potassium was found in a tree growing in the Japanese Garden and the lowest in the trees growing on Radarowa Street and Snopkowa Street (Table 4).

Table 4. Selected nutrients content in the needles of trees of family Taxodiaceae growing in the Wrocław area

Tabela 4. Zawartość wybranych pierwiastków w igłach drzew z rodziny Taxodaiceae rosnących na terenie Wrocławia

\begin{tabular}{|c|c|c|c|c|c|c|}
\hline \multirow{2}{*}{$\begin{array}{c}\text { Stand } \\
\text { Stanowisko }\end{array}$} & & \multicolumn{5}{|c|}{$\begin{array}{l}\text { Selected nutrients [\% of dry weight] } \\
\text { Wybrane składniki [\% suchej masy] }\end{array}$} \\
\hline & & $\mathrm{Mg}$ & $P$ & $\mathrm{Ca}$ & $\mathrm{K}$ & $\mathrm{N}$ \\
\hline \multicolumn{7}{|c|}{ Japanese cedar Cryptomeria japonica - Szydlica japońska } \\
\hline $\begin{array}{l}\text { Japanese Garden } \\
\text { Ogród japoński }\end{array}$ & & 0.14 a & $0.10 \mathrm{a}$ & $0.63 \mathrm{c}$ & $0.88 \mathrm{a}$ & $1.44 \mathrm{a}$ \\
\hline $\begin{array}{l}\text { Radarowa Street } \\
\text { Ulica Radarowa }\end{array}$ & & $0.14 \mathrm{a}$ & $0.09 \mathrm{a}$ & $0.92 \mathrm{~b}$ & $0.58 \mathrm{~b}$ & $1.44 \mathrm{a}$ \\
\hline $\begin{array}{l}\text { Snopkowa Street } \\
\text { Ulica Snopkowa }\end{array}$ & & 0.13 a & 0.08 a & 0.98 a & $0.48 \mathrm{~b}$ & $1.44 \mathrm{a}$ \\
\hline \multicolumn{7}{|c|}{ Baldcypress Taxodium distichum - Cypryśnik błotny } \\
\hline \multirow{5}{*}{$\begin{array}{l}\text { Szczytnicki Park } \\
\text { Park Szczytnicki }\end{array}$} & 1 & $0.17 \mathrm{c}$ & $0.09 \mathrm{a}$ & $0.43 \mathrm{e}$ & $0.75 \mathrm{a}$ & $1.16 \mathrm{~cd}$ \\
\hline & 2 & $0.22 \mathrm{a}$ & $0.05 \mathrm{bc}$ & $0.45 \mathrm{de}$ & $0.50 \mathrm{e}$ & $1.21 \mathrm{bc}$ \\
\hline & 3 & $0.18 \mathrm{ab}$ & $0.09 \mathrm{a}$ & $0.45 \mathrm{de}$ & $0.70 \mathrm{ab}$ & $1.13 \mathrm{~d}$ \\
\hline & 4 & $0.19 a b$ & $0.07 \mathrm{ab}$ & $0.53 \mathrm{~b}$ & $0.58 \mathrm{~d}$ & $1.34 \mathrm{a}$ \\
\hline & 5 & $0.19 a b$ & $0.08 \mathrm{ab}$ & $0.48 \mathrm{~cd}$ & $0.60 \mathrm{~d}$ & $1.28 \mathrm{ab}$ \\
\hline \multirow{2}{*}{$\begin{array}{l}\text { South Park } \\
\text { Park Wschodni }\end{array}$} & 1 & $0.19 a b$ & $0.09 \mathrm{a}$ & $0.43 \mathrm{e}$ & $0.63 \mathrm{~cd}$ & $1.07 \mathrm{de}$ \\
\hline & 2 & $0.21 \mathrm{a}$ & $0.04 \mathrm{bc}$ & $0.53 \mathrm{~b}$ & $0.23 \mathrm{f}$ & $1.08 \mathrm{de}$ \\
\hline \multicolumn{2}{|l|}{$\begin{array}{l}\text { Norwida Street } \\
\text { Ulica Norwida }\end{array}$} & $0.16 \mathrm{bc}$ & $0.03 \mathrm{c}$ & $0.50 \mathrm{bc}$ & 0.68 bc & $1.12 \mathrm{~d}$ \\
\hline \multicolumn{2}{|l|}{$\begin{array}{l}\text { Jarzębinowa Street } \\
\text { Ulica Jarzębinowa }\end{array}$} & $0.13 \mathrm{c}$ & $0.05 \mathrm{bc}$ & $0.35 \mathrm{f}$ & $0.60 \mathrm{~d}$ & 1.02 e \\
\hline \multicolumn{2}{|l|}{$\begin{array}{l}\text { Strachociński Park } \\
\text { Park Strachociński }\end{array}$} & $0.19 a b$ & $0.04 \mathrm{bc}$ & $0.58 a$ & $0.58 \mathrm{~d}$ & $1.28 \mathrm{ab}$ \\
\hline \multicolumn{2}{|l|}{$\begin{array}{l}\text { Pilczycka Street } \\
\text { Ulica Pilczycka }\end{array}$} & $0.19 a b$ & $0.05 \mathrm{bc}$ & $0.48 \mathrm{~cd}$ & $0.75 a$ & $1.33 \mathrm{a}$ \\
\hline \multicolumn{7}{|c|}{ Dawn redwood Metasequoia glyptostroboides - Metasekwoja chińska } \\
\hline \multirow{6}{*}{$\begin{array}{l}\text { Japanese Garden } \\
\text { Ogród japoński }\end{array}$} & 1 & $0.25 \mathrm{bc}$ & $0.16 \mathrm{~cd}$ & 0.50 ef & $1.58 \mathrm{~b}$ & $1.97 \mathrm{~b}$ \\
\hline & 2 & $0.23 \mathrm{c}$ & $0.18 \mathrm{c}$ & $0.60 \mathrm{~d}$ & $0.95 \mathrm{~d}$ & $1.45 \mathrm{e}$ \\
\hline & 3 & $0.22 \mathrm{c}$ & $0.27 \mathrm{ab}$ & $0.45 \mathrm{f}$ & $1.78 \mathrm{a}$ & $1.84 \mathrm{c}$ \\
\hline & 4 & $0.28 \mathrm{ab}$ & $0.25 \mathrm{~b}$ & $0.88 \mathrm{~b}$ & $1.03 \mathrm{~d}$ & $1.87 \mathrm{bc}$ \\
\hline & 5 & $0.22 \mathrm{c}$ & $0.32 \mathrm{a}$ & $0.78 \mathrm{c}$ & $1.23 \mathrm{c}$ & $1.84 \mathrm{c}$ \\
\hline & 6 & $0.30 \mathrm{a}$ & $0.12 \mathrm{de}$ & $0.98 \mathrm{a}$ & $1.20 \mathrm{c}$ & $2.31 \mathrm{a}$ \\
\hline \multirow{2}{*}{$\begin{array}{l}\text { Szczytnicki Park } \\
\text { Park Szczytnicki }\end{array}$} & 1 & $0.29 \mathrm{a}$ & $0.18 \mathrm{c}$ & $0.55 \mathrm{de}$ & $1.18 \mathrm{c}$ & $1.81 \mathrm{c}$ \\
\hline & 2 & $0.23 \mathrm{c}$ & $0.07 \mathrm{e}$ & $0.60 \mathrm{~d}$ & $0.95 \mathrm{~d}$ & $1.70 \mathrm{~d}$ \\
\hline $\begin{array}{l}\text { Orłowskiego Street } \\
\text { Ulica Orłowskiego }\end{array}$ & & $0.14 \mathrm{~d}$ & $0.07 \mathrm{e}$ & $0.58 \mathrm{~d}$ & $1.00 \mathrm{~d}$ & $1.53 \mathrm{e}$ \\
\hline
\end{tabular}

Explanations see Table 1 - Objaśnienia zob. tab. 1.

Baldcypres performed at 6 stands, among which the largest one was recorded in Szczytnicki Park, where grew 5 trees planted by the water reservoir. Four of them grew in the group and the last one was at the distance for about $400 \mathrm{~m}$. The second stand of baldcypress was recorded in South Park, where two trees grew very close to each other $(3 \mathrm{~m})$. At other positions trees were growing individually: Norwida Street 22 in the courtyard of the tenement at a distance of $2 \mathrm{~m}$ from the wall of the building; Jarzębinowa Street in the school 
playground; Strachociński Park at the water reservoir; Pilczycka Street on the lawn. All of the trees growing as an individuals were yielding cones. The highest tree with the largest trunk circumference grew in Szczytnicki Park and the tree with the smallest trunk circumference was also found in this place. The lowest was the tree growing in Strachociński Park (Table 1).

Soil $\mathrm{pH}$ varied within the stands where the baldcypress was grown. In the topsoil, apart from results belonging simultaneously to both statistically homogenous groups, the lowest $\mathrm{pH}$ was found in the soil derived from Szczytnicki Park and Jarzębinowa Street, while the highest in the soil from Pilczycka Street. In the subsoil the highest pH was observed in soil from Strachociński Park and the lowest in soil from Norwida Street. For the topsoil the highest EC was recorded in the soil from Pilczycka Street, while the lowest from Norwida Street. The highest EC in the subsoil was measured in soil from South Park, while the lowest from Jarzębinowa Street. According to limit values of macronutrients in mineral soils, the analysis of soil from stands of baldcypress showed differences in richness of tested nutrients. Magnesium content differed within stands, as well as within soil layers. Soil richness in this nutrient varied from very low to very hight. The highest content of magnesium in the topsoil was noted in Strachociński Park, the lowest in the soil from Pilczycka Street. In the subsoil the highest content of magnesium was in the soil from Pilczycka Street, while the lowest on Norwida Street. The highest content of calcium in the topsoil occurred in Strachociński Park, the lowest in Szczytnicki Park. The richest in calcium was subsoil from South Park, the lowest content of this nutrient was noted on Norwida Street. Soil richness in phosphorus varied between very low and low. The highest phosphorus content in both soil layers showed soil from Jarzębinowa Street. The lowest content of phosphorus was found in the topsoil from Szczytniki Park and in the subsoil of Szczytnicki Park and South Park. Potassium content in soil varied from very low to high. The highest potassium content in both soil layers was observed in Strachociński Park. The lowest potassium content in the topsoil was noted in Szczytnicki Park, South Park and Jarzębinowa Street, while in the subsoil only in the soil coming from South Park. In both layers of soil, the highest content of nitrate nitrogen was found in the soil from Pilczycka Street and the lowest showed the soil samples from South Park (Table 2).

The highest content of chlorophyll a and total chlorophyll was found in baldcypress growing on Norwida Street, while the highest content of chlorophyll b had one of the trees from Szczytnicki Park. The lowest content of chlorophyll a was reported in the tree from Jarzębinowa Street, total chlorophyll from Strachociński Park and chlorophyll b in trees from both of previously mentioned stands (Table 3).

The nutrition level of baldcyprees needles depended on the stand. The highest magnesium content was found mostly in the trees growing in Szczytnicki Park (one of 5 trees showed low content of this nutrient), South Park and Strachociński Park and also in a tree growing on Pilczycka Street. Lower nutrition level with this element was observed in trees from Norwida Street and Jarzębinowa Street. The highest level of potassium had 4 out of 5 trees from Szczytnicki Park and one of the two trees from South Park. All of the other trees showed lower level of nutrition by this element. The highest content of calcium was found in needles of baldcypress growing in Strachociński Park, while the lowest in the tree from Jarzębinowa Street. The highest potassium content was found in two of the five trees from 
Szczytnicki Park and a tree from Pilczycka Street, while the lowest in the tree growing on Norwida Street. The best nitrogen nutrition showed also two out of five trees from Szczytnicki Park, as well as tree from Strachociński Park and Pilczycka Street. The lowest nitrogen content occurred in needles of two trees from South Park and Jarzębinowa Street (Table 4).

Dawn redwood was growing at three stands: in the Japanese Garden were recorded six trees, in Szczytnicki Park grew two trees and one tree was noted on private estate at Orłowskiego Street. The stand of dawn redwood in Szczytnicki Park was located in the neighborhood of the largest position of baldcypress. The highest tree with the largest trunk circumference was one of the trees in the Japanese Garden. The smallest trunk circumference had the tree growing in Szczytnicki Park. The lowest was the tree from Orłowskiego Street (Table 1).

According to limit values of macronutrients in mineral soils, the analysis of soil from stands of Japanese cedar showed differences in richness of tested nutrients.. Differences in $\mathrm{pH}$ depended on stands were found only in the topsoil, in the subsoil differences were statistically insignificant. In the topsoil the highest $\mathrm{pH}$ was reported in the Japanese Garden, while the lowest in Szczytnicki Park and on Orłowskiego Street. EC of the analyzed soils was very low and the highest for both layers was recorded in Szczytnicki Park. The lowest EC was noted in the topsoil of the Japanese Garden and subsoil of both the Japanese Garden and Orłowskiego Street. Magnesium content in both layers was classified as medium, with the exception of subsoil from Szczytnicki Park, where the content of this nutrient was low. Statistically, in both layers of the soil profile the highest magnesium content was found in soil from Japanese Garden. The highest calcium content in the topsoil was found in the soil from Japanese Garden, while the lowest in the topsoil from Szczytnicki Park and Orłowskiego Street. In the subsoil the highest content of calcium occurred in soil from Szczytnicki Park and Orłowskiego Street, while the lowest was in subsoil from the Japanese Garden. Potassium and phosphorus content in both soil layers reached the highest values in soil derived from the Japanese Garden, while the lowest content of these nutrients was found in soil from Szczytnicki Park. However, in both soil layers the contents of phosphorus and potassium was determined as very low, with the tendency to obtain by subsoils higher contents of tested nutrient. The highest content of nitrate nitrogen, both in the topsoil and in the subsoil, was observed in the soil from Szczytnicki Park, while the lowest in the soil of the Japanese Garden (Table 2).

The highest content of chlorophyll a, chlorophyll $b$ and total chlorophyll, as well as the lowest contents of these chlorophylls, characterized by one of the trees growing in the Japanese Garden (Table 3).

The level of dawn redwood needles depended on the stand. The best nourishment with magnesium showed two of six trees from the Japanese Garden and the tree growing in Szczytnicki Park. The lowest magnesium content was reported in the tree from Orłowskiego Street. The highest phosphorus content had one out of the trees from the Japanese Garden, while the lowest one of the trees from Szczytnicki Park and tree from Orłowskiego Street. In the case of calcium, both the highest and the lowest content of this nutrient, was observed in trees growing in the Japanese Garden. The highest potassium content was found in needles 
of one of the trees from Japanese Garden and the lowest in one of the trees from Szczytnicki Park and in tree from Orłowskiego Street. The best nourished with nitrogen were needles from one of the tree growing in the Japanese Garden, while the lowest content of this nutrient was found also in one of the trees from the Japanese Garden and in the tree from Orłowskiego Street (Table 4).

\section{DISCUSSION}

Results of this research show that baldcypress, dawn redwood and Japanese cedar are able to grow in conditions of Wrocław city. The urban environment is characterized by, among others, anthropogenic transformation of the soil (e.g. a high concentration of salts and heavy metals content) and low air humidity, which affects the limited selection of trees and shrubs to urban conditions (Bugała et al. 1984; Czekalski and Grochowski 2001). Species belonging to Taxodiaceae family, to be examined in the Wrocław city, grow in both anthropogenically transformed areas and stands in parks, which retain the primeval riparian and broadleaved forests. For the trees from Taxodiaceae family the most suitable places for growth are large parks (Szymanowski 1957). Baldcypress best grow and develop while seated near the large water tank, as it takes place in Wrocław. Three out of the five trees in Szczytnicki Park in the immediate neighborhood of water reservoir were the highest. Although the content of magnesium, calcium, potassium and phosphorus in the soil was lower than in most of the other stands of its occurrence, the trees had higher contents of magnesium and potassium in their needles than trees growing in other stands.

According to Keim et al. (2012) water level, especially excessive flooding, was a key factor determining baldcypress growth more than nutrient deficiencies. In the case of baldcypress growing in Szczytnicki Park there were noted no visible nutrient deficiencies, as well as no negative impact on the trees growth due to the close neighborhood of the water reservoir. Megonigal and Day (1992) observed a tendency to stronger growth of aboveground part of young baldcypress trees on the areas periodically flooded, and although in Wrockaw such phenomenon does not occur, the trees on all of the stands grew well. It is assumed that in Poland baldcypress grows up to 25 meter high and most of the examined trees exceeded this value. Dawn redwood also are able to grow in city greeneries, what coincides with the announcement of Gilman and Watson (1994a) of a high tolerance of these species to environmental pollutions. They also indicate that dawn redwood does not tolerate the high $\mathrm{pH}$ and grows the best in slightly acidic soils.

On most stands in Wrocław the soil pH is alkaline. This is due to the strong enrichment of soil in $\mathrm{CaCO}_{3}$, as a result of human activity through limestone debris or dust accumulation, which decomposes very slowly. In those kind of soils, the limestone debris is often mixed with a humus layer (Drozd 1998). In dawn redwood cultivation the $\mathrm{pH}$ reaches even 7.6 in the topsoil of Japanese Garden, despite this the trees grew well and showed no physiological reaction to alkaline. Japanese cedar prefers moist and moderately fertile soil but according to Gilman and Watson (1993) shows no negative reaction to drought and survives in the urban greenery areas during periods of water shortages in the summer. Sawata and Kato $(1991,1993,2007)$ noted that Japanese cedar has a unique ability to 
accumulate calcium in the topsoil. Moreover, Baba et al. (2004) observed that the launch of calcium from level 0 immobilizes the calcium in the topsoil layer (0-20) resulting in inhibition of soil acidification in forests. In the case of Japanese cedar growing in Wrocław, slightly lower calcium content in the topsoil compared to subsoil performed at stands on Radarowa Street and Snopkowa Street but in both layers' soil was alkaline. Tanikawa et al. (2014) reported higher magnesium and potassium content in the topsoil while in own study the subsoil was richest in these nutrients.

Studies have shown that both chlorophyll content and selected nutrients content in needles of trees needles is an individual trait. Trees growing in the same stands often indicated extreme chlorophyll or nutrients content, although the soil fertility was the same. Such individual response may depend in the health status of the individual but also a number of external factors, like shading degree of trees, soil volume easily outgrown by root system or the neighborhood of other species that may influence on the tree development. In the examined taxa the chlorophyll content differed within them depending on the stands, and in the case of dawn redwood also noted differences in chlorophyll content also within the stand - the Japanese Garden - where grew both trees with the highest and the lowest contents of measured chlorophylls.

According to Tuzhilkina (2001) the content of total chlorophyll in the trees is relatively constant if they grow in optimal conditions, while the chlorophyll a and b may differ during the growing season and this changes are a response to differences in light conditions, level of nutrition, humidity, temperature and other factors. Khan et al. (2000) showed that chlorophyll a content, both in older and young needles, increased with shading degree of examined conifer taxa (ponderosa pine, Douglas fir, western red cedar, western hemlock). On the other hand (Han et al. 2015) noted, that on warmer stands the content of chlorophyll A and total chlorophyll in Japanese red pine was higher, in Korean pine decrease and in both Korean fir and Manchurian fir were observed no significant changes. Nutritional status of examined trees, like the chlorophyll content, differed not only within species depending on stands but also on a given stand within individuals of a given species. Despite the statistical differences in the content of selected macronutrients in the needles, none of the trees showed visible nutrient deficiencies. The differences in the selected nutrients content in needles of given taxa within one stands, which can be seen particularly strong in the case of dawn redwood, may result from the immediate neighborhood of other species or lack of them.

According to (Thelin et al. 2002) in the needles of spruce growing on mixed stands was noted the highest concentration of nitrogen, potassium and phosphorus in comparison to spruce monoculture. Moreover, it was noted that the level of spruce nutrition in monoculture on fertile stands was comparable with the level of trees nutrition from mixed stands on poor soils. This underlines the importance of species diversity, which has a direct impact on nutrients content in plants.

\section{CONCLUSIONS}

It is an interesting fact that trees belonging to Taxodiaceae family, and especially baldcypress, tolerate quite well even harmful urban conditions and reach large sizes. This is confirmed by the tree growing in the center of the courtyard on Norwida Street 22 planted about 2 meters from the 5 -storey residential building. 
All three studied taxa were able to grow in the greenery of Wrocław city, showing a high flexibility to soil $\mathrm{pH}, \mathrm{EC}$ and selected nutrients contents in the soil. Despite the differences in chlorophyll content and needles nutrition with selected macronutrients, none of the tested trees showed visible nutrient deficiencies. These results show that tested species can grow in the greeneries of Wrocław city.

\section{REFERENCES}

Baba M., Kato M., Sugiura T., Kobayashi H. 2004. Calcium accumulation alleviates soil acidification in Japanese cedar (Cryptomeria japonica) stands. Soil Sci. Plant Nutr. 50, 403-411.

Bartholomew B., Boufford D.E., Spongberg S.A. 1983. Metasequoia glyptostroboides - its present status in China. J. Arnold Arbor. 64, 105-128.

Bąbelewski P. 2006. Drzewa i krzewy miasta Lądek Zdrój, w: Bogactwo, różnorodność oraz ochrona dendroflory w parkach i lasach zachodniej Polski. Materiały Zjazdu Sekcji Dendrologicznej Polskiego Towarzystwa Botanicznego, Zielona Góra 22-24.06.2006. Red. W. Danielewicz. Poznań, [b.w.], 55-56. [in Polish]

Bugała W., Chylarecki H., Bojarczuk T. 1984. Dobór drzew i krzewów do obsadzania ulic i placów w miastach z uwzględnieniem kryteriów rejonizacji [Trees and shrubs for lining streets and squares of the cities taking into account the criteria of regionalization]. Arbor. Kór. 29, 35-62. [in Polish]

Chu K.L., Cooper W.S. 1950. An ecological reconnaissance in the native home of Metasequoia glyptostroboides. Ecology 31, 260-278.

Czekalski M., Grochowski T. 2001. Naturalne obsiewanie się drzew i krzewów na terenie Ogrodu Botanicznego Uniwersytetu Wrocławskiego w 1999 roku [Natural seeds spreading of trees and shrubs in Botanical Garden of Wrocław University in 1999]. Rocz. Dendrol. 49, 287-295. [in Polish]

Drozd J. 2002. Środowisko glebowe na terenach zieleni miejskiej, w: Miasto-ogród. Sto lat rozwoju idei. Konferencja Naukowa, Wrocław 18-20.06.1998. Wrocław, Dolnośląskie Wydaw. Nauk., 29-34. [in Polish]

Dubicka M. 2000. Klimat Wrocławia, w: Encyklopedia Wrocławia. Red. J. Harasimowicz. Wrocław, Wydaw. Dolnośląskie, 356-357. [in Polish]

Dubicka M., Chudzia D. 2002. Mobilna meteorologiczna stacja pomiarowa w badaniach klimatu aglomeracji miejskiej Wrocławia [Mobile meteorological testing station in study on climate of Wrocław city agglomeration]. Acta Univ. Vratislav. ENO, Pr. Inst. Geograf., Ser. C 5, 107-112. [in Polish]

Dubicka M., Szymanowski M. 2000. Struktura miejskiej wyspy ciepła i jej związek z warunkami pogodowymi i urbanistycznymi Wrocławia [Structure of urban heat island and its connection with weather and urban conditions of Wrocław]. Acta Univ. Vratislav., Stud. Geograf. 74, 99-117. [in Polish]

Dubicka M., Dubicki A., Szymanowski M. 2002. Klimat Wrocławia. Informator o stanie środowiska Wrocławia. Wrocław, Dolnośląska Fundacja Ekorozwoju, 9-25. [in Polish]

Dubicka M., Dubicki A. 2006. Środowisko Wrocławia. Cz. I. Wrocław, Instytut Ochrony Środowiska, 10-91. [in Polish]

Faithfull N.T. 2002. Methods in agricultural chemical analysis: a practical handbook. New York, USA, CAB Publishing.

Gilman E.F., Watson D.G. 1993. Cryptomeria japonica 'Yoshino'. 'Yoshino' Japanese-Cedar. Fact Sheet ST-219. [b.m.], US Forest Service, Department of Agriculture.

Gilman E.F., Watson D.G. 1994a. Metasequoia glyptostroboides. Dawn Redwood. Fact Sheet ST-407. [b.m.], US Forest Service, Department of Agriculture. 
Gilman E.F., Watson D.G. 1994b. Taxodium distichum. Baldcypress. Fact Sheet ST-620. [b.m.], US Forest Service, Department of Agriculture.

Han S., Lee S.J., Yoon T.K., Han S.H., Lee J., Kim S., Hwang J., Cho M.S., Son Y. 2015. Species-specific growth and photosynthetic response of first-year seedlings of four coniferous species to open-field experimental warming. Turk. J. Agric. For. 39, 342-349.

Hendricks D.R., Søndergaard P. 1998. Metasequoia glyptostroboides 50 years out of China. Observations from the United States and Denmark. Dansk Dendr. Arsskrift 6, 6-24.

Hrynkiewicz-Sudnik J. 1977. Park w Sulistrowicach [Park in Sulistrowice]. Rocz. Dendrol. 30, 95-102. [in Polish]

Hu H.H., Cheng W.C. 1948. On the new family Metasequoiaceae and on Metasequoia glyptostroboides, a living species of the genus Metasequoia found in Szechuan and Hupen. The Bull. Fan. Memor. Inst. Biol., New Ser. 1, 153-161.

Keim R.F., Izdepski C.W., Day J.W. Jr. 2012. Growth responses of baldcypress to wastewater nutrient additions and changing hydrologic regime. Wetlands 32(1), 95-103.

Khan S.R., Rose R., Haase D.L., Sabin T.E. 2000. Effects of shade on morphology, chlorophyll concentration and chlorophyll fluorescence of four Pacific Northwest conifer species. New Forests 19(2), 171-186.

Kuser J.E. 1999. Metasequoia glyptostroboides: fifty years of growth in North America. Arnoldia 58(1), 76-79.

Megonigal J.P., Day F.P. 1992. Effects of flooding on root and shoot production of bald cypress in large experimental enclosures. Ecology 73(4), 1182-1193.

Miki S. 1941. On the change of flora in eastern Asia since Tertiary Period. I. The clay or lignite beds flora in Japan with special reference to the Pinus trifolia beds in Central Hondo. Jpn. J. Bot. 3(11), 377-303.

Nagakura J., Shigenaga H., Akama A., Takahashi M. 2004. Growth and transpiration of Japanese cedar (Cryptomeria japonica) and Hinoki cypress (Chamaecyparis obtusa) seedlings in response to soil water content. Tree Physiol. 24, 1203-1208.

Nowosielski O. 1974. Metody oznaczania potrzeb nawożenia. 2nd edition. Warszawa, PWRiL, 91. [in Polish]

Sawata S., Kato H. 1991. Effect of forest on soil. Part 2. The base accumulation and other soil properties related to age of Cryptomeria and Hinoki cypress stands. Jpn. J. Soil Sci. Plant Nutr. 62, 49-58

Sawata S., Kato H. 1993. Effect of forest on soil. Part 4. Factors concerning the base accumulation in Sugi and Hinoki soils. Jpn. J. Soil Sci. Plant Nutr. 64, 296-302.

Sawata S., Kato H. 2007. Chemical properties of surface soil in relation to the quantity of stemflow, through fall and litter in a mixed forest of Japanese cedar (Cryptomeria japonica) and Beech (Fagus crenata) trees. Jpn. J. Soil Sci. Plant Nutr. 49, 93-101.

Sreenivasan A., Sadivasan V. 1939. Estimation of nitrogen by the Kjedahl method: Nature of the action of selenium. Anal. Chem. 11(6), 314-315.

Szymanowski T. 1957. Cypryśnik błotny - Taxodium distichum Rich. i jego występowanie w naszych parkach [Baldycpress - Taxodium distichum Rich. and its occurrence in our parks]. Rocz. Dendrol. 12, 35-62. [in Polish]

Tanikawa T., Sobue A., Hirano Y. 2014. Acidification processes in soils with different acid buffering capacity in Cryptomeria japonica and Chamaecyparis obtusa forests over two decades. Forest Ecol. Manag. 334, 284-292.

Thelin G., Rosengren U., Callesen I., Ingerslev M. 2002. The nutrient status of Norway Spruce in pure and in mixed-species stands. Forest Ecol. Manag. 160(1-3), 115-125.

Tuzhilkina V.V. 2001. Pigment system of coniferous from the region of Syktyvkar Timber Industry Complex. Vest. Inst. Biol. Kom. NTs Ural Otd. Ross. Akad. Nauk. 47, 22-25. 


\begin{abstract}
Trees belonging to Taxodiaceae family are rarely grown in Polish climatic conditions due to their origin from the warmer regions of the world. The aim of this study was to develop the nutritional status of trees of family Taxodiaceae growing in the Wrocław areas, which have preserved characteristics of the primeval riparian and broadleaved forests, as well as on the anthropogenically transformed stands. In 2013 in the Wrocław area were localized 3 sites of Japanese cedar where 3 trees were found to grow. Dawn redwood grown on 2 sites, total 9 trees. Six sites of baldcypress were noted, where grown 11 trees. Despite the differences in chlorophyll content and nutrients content, none of the trees showed visible nutrient deficiencies. This results indicate that trees of family Taxodiaceae can grow on the greeneries of Wrocław city.
\end{abstract}

